\title{
PENGARUH EDUKASI SELF MANAGEMENT DIABETES (DSME) DENGAN MEDIA BOOKLET TERHADAP KEPATUHAN DIET PASIEN DM TIPE 2 DI PUSKESMAS CIMAHI SELATAN
}

\author{
Siti Aminah ${ }^{1 *}$, Kiki Rizki Amelia ${ }^{2}$, Budi Rianto ${ }^{3}$, Vicky Diah Safitri ${ }^{4}$ \\ ${ }^{1-4}$ STIKes Budi Luhur Cimahi \\ Email Korespondensi: st.amie63@gmail.com \\ Disubmit: 24 Januari 2022 Diterima: 27 Januari 2022 Diterbitkan: 02 Februari 2022 \\ DOI: https://doi.org/10.33024/mnj.v5i2.5912
}

\section{ABSTRACT: THE EFFECT OF DIABETES SELF MANAGEMENT EDUCATION (DSME) WITH MEDIA BOOKLET ON DIET COMPLIANCE WITH TYPE 2 DM PATIENTS AT THE PUBLIC HEALTH CENTER SOUTH CIMAHI}

Introduction: Diabetes Mellitus be cured, but patients can maintain/control their condition in order to live a healthier life. One of the efforts to improve the ability of self-care in DM patients is Diabetes Self-Management Education (DSME). The 5 main pillars of handling type 2 DM are education, medical nutrition diet, physical exercise, pharmacology and monitoring of glucose levels. Purpose: The purpose of this study was to determine the effect of DSME with media booklet on dietary compliance in patients with type 2 diabetes.

Method: The research method that used is pre-experiment design with one pretest group. Sampling techniques in this study used samples accidentally with a total of 16 respondents according to the included criteria and the exception. The analysis is using monemar.

Result: The results of this study found that before the intervention of respondents who do not adhere to diet were 13 (81.3\%), and after given intervention of respondents that adherent were 13 (81.3\%). There is influence of the media DSME booklet on dietary compliance of patients DM type 2 at the South Cimahi Public Health Center withvalue $p=0.006=0.05$.

Conclusion: The results of the study can be concluded that there is an effect of DSME with media booklet on the dietary compliance of type 2 DM patients at the South Cimahi Public Health Center. Suggestions from this study are expected to be used as additional scientific knowledge in the field of nursing to reduce the incidence of DM.

Keywords : DSME, Dietary Compliance, Media Booklet, DM

INTISARI: PENGARUH EDUKASI SELF MANAGEMENT DIABETES (DSME) DENGAN MEDIA BOOKLET TERHADAP KEPATUHAN DIET PASIEN DM TIPE 2 DI PUSKESMAS CIMAHI SELATAN

Pendahuluan: Penyakit DM tidak dapat disembuhkan, namun penderita dapat menjaga/mengontrol kondisinya agar dapat hidup lebih sehat. Salah satu upaya 
untuk meningkatkan kemampuan perawatan mandiri pada pasien DM yaitu dengan Diabetes Self Management Education (DSME). 5 pilar penanganan utama DM tipe 2 yaitu edukasi, diet nutrisi medik, latihan jasmani, farmakologi dan monitoring kadar glukosa.

Tujuan: Tujuan dari penelitian ini untuk mengetahui adanya pengaruh DSME dengan media booklet terhadap kepatuhan diet pada penderita DM tipe 2.

Metode Penelitian: Metode penelitian menggunakan Praexperiment dengan desain One Grup Pretest Posttest.Teknik pengambilan sampel dalam penelitian ini menggunakan purposive sampling dengan jumlah 16 responden yang sesuai dengan kriteria inklusi dan eksklusi. Uji analisis menggunakan McNemar.

Hasil: Hasil penelitian ini didapatkan bahwa sebelum intervensi responden yang tidak patuh pada dietnya sebanyak $13(81,3 \%)$, dan setelah diberikan intervensi responden yang patuh sebanyak $13(81,3 \%)$.Terdapat pengaruh DSME dengan media booklet terhadap kepatuhan diet pasien DM tipe 2 di Puskesmas Cimahi Selatan dengan nilai $p=0,006 \leq \alpha=0,05$.

Kesimpulan: Hasil penelitian dapat disimpulkan bahwa terdapat pengaruh DSME dengan media booklet terhadap kepatuhan diet pasien DM tipe 2 di Puskesms Cimahi Selatan.Saran dari penelitian ini yaitu iharapkan dapat dijadikan tambahan wawasan keilmuan bidang keperawatan untuk mengurangi angka kejadian DM.

Kata Kunci : DSME, Kepatuhan Diet, Media Booklet, DM

\section{PENDAHULUAN}

Diabetes mellitus (DM) merupakan suatu kelompok penyakit metabolik dengan karakteristik hiperglikemia yang terjadi karena kelainan sekresi insulin, kerja insulin, atau kedua-keduanya. DM dapat diklasifikasikan menjadi beberapa tipe yakni, DM ripe $1, D M$ tipe 2, DM tipe yang ada. DM tipe 2 merupakan salah satu jenis yang paling banyak di temukan yaitu lebih dari 90-95 \% (A. D. Association, 2016).

Diabetes melitus (DM) adalah penyebab utama morbiditas kematian serta memiliki dampak yang signifikan terhadap kualitas hidup pasien. Dalam laporan World Health Organization (WHO) tahun 2018 tercatat bahwa DM menduduki peringkat ke-6 sebagai penyebab kematian di dunia. Pada tahun 2019, diperkirakan 4,2 juta orang dewasa berusia 20-79 tahun akan meninggal karena diabetes, terhitung $11,3 \%$, 1,9 juta di perkirakan terjadi pada orang dewasa yang lebih muda dari 60 tahun (Malanda, 2019).

Penyakit diabetes mellitus dan gangguan metabolik masuk dalam salah satu program dan indikator yang dilaksanakan oleh Direktorat P2PTM. Peningkatan prevalensi PTM di negara berkembang mendorong tercetusnya kesepakatan tentang strategi global pencegahan dan pengendalian penyakit tidak menular. PTM telah menjadi isu strategis dalam agenda SDGs 2030 sehingga harus menjadi prioritas pembangunan di setiap negara. Dalam management penyakit tidak menular disebutkan indikator SDGs adalah angka kematian dini akibat penyakit tidak menular menurun hingga sepertiga pada tahun 2030 dengan salah satu target globalnya yang pertama yaitu penurunan kematian dini akibat PTM 25\% tahun 2025 (Kemenkes, 2019).

Menurut Riset Kesehatan Dasar jumlah penderita DM di Indonesia telah mencapai 8,4 juta dan 
menduduki peringkat 4 terbanyak pada dunia setelah Amerika, Cina, dan India di tahun 2018 dari tahun 2014 sampai 2018 jumlahnya meningkat hampir 2 kali lipat dan Jawa Barat merupakan propinsi dengan angka kejadian tertinggi dengan 1,5 juta orang yang berusia 15 tahun ke atas (Depkes, 2018).

Berdasarkan data Dinas kesehatan Kota Cimahi tahun 2018 didapatkan angka penderita diabetes di Puskesmas Kota Cimahi sebanyak 10821 kasus. Jumlah kasus baru DM di kota Cimahi sebanyak 1224 kasus pada laki-laki dan wanita ada sebanyal 2377 kasus. Faktor risiko yang terbesar dari kasus DM adalah perubahan gaya hidup kurang aktivitas fisik diet tidak sehat dan tidak seimbang, mempunyai berat badan lebih (obesitas), hipertensi, hipercholesterolemi dan konsumsi alkohol serta konsumsi tembakau (merokok) (Dinkes, 2018).

Penyakit DM tidak dapat disembuhkan, namun penderita dapat menjaga/mengontrol kondisinya agar dapat hidup lebih sehat. Untuk mengurangi hal tersebut diperlakukan suatu program penatalaksanaan diabetes dimana terdapat pengaturan pola makan, aktifitas dan olahraga. Oleh karena itu dibutuhkan kemampuan untuk mengelola perilaku sendiri. Kemampuan ini sering disebut Self Management. Diabetes Self Management Education (DSME) merupakan upaya yang dapat dilakukan perawat untuk memberikan edukasi secara berkelanjutan bagi klien DM (CA, 2016).

Funnel, Brown, Childs, Haas, Hosey, dkk (2012) juga mengatakan salah satu pendidikan yang dapat membantu pasien DM tipe 2 adalah Diabetes Self Management Education (DSME) atau disebut dengan pendidikan manajemen diri. Diabetes Self Management
Education (DSME) adalah proses untuk mengajari orang mengelola diabetesnya, salah satunya telah dianggap sebagai bagian penting dari manajemen klinis diabetes sejak tahun 1930an. DSME adalah proses kolaboratif dimana pendidik diabetes membantu orang dengan atau beresiko diabetes memperoleh pengetahuan dan pemecahan masalah dan keterampilan koping yang diperlukan untuk mengatasi mengelola penyakit dan kondisi yang terkait secara mandiri.

Pendidikan (edukasi) kesehatan merupakan bentuk upaya persuasi atau pembelajaran kepada masyarakat bersedia melakukan tindakan-tindakan untuk memelihara dan meningkatkan taraf kesehatannya, mencegah timbulnya penyakit, mempertahankan taraf kesehatan yang sudah ada,memaksimalkan fungsi dan peran pasien selama sakit serta membantu pasien dan keluarga mengatasi masalah kesehatan (Notoatmodjo., 2013). Titik berat metode Pendidikan kesehatan adalah cara efektif dan efisien untuk menanamkan belajar bermakna. Pendidikan kesehatan dengan metode penyuluhan berpengaruh terhadap kepatuhan pasien menjalankan diet dalam menurunkan kadar gula darah

(Fitri Suciana, 2019) menyatakan bahwa ada 5 pilar penanganan utama pada pasien DM tipe 2 yaitu edukasi, diet nutrisi medik, latihan jasmani, obat farmakologi dan monitoring kadar gula darah. Edukasi memegang peranan yang sangat penting dalam penatalaksanaan DM tipe 2 karena pemberian edukasi kepada pasien dapat merubah perilaku pasien dalam melakukan perawatan mandiri diabetes melitus. Merubah perilaku pada penyandang Diabetes tidak mudah, diperlukan motivasi yang diakukan secara terus menerus. 
Motivasi yang diperlukan dapat dengan berbagai cara salah satunya dengan memberikan edukasi untuk selalu mengingatkan tentang perawatan penyandang Diabetes Melitus (5 pilar) setiap saat. Edukasi yang diberikan secara langsung sudah sering dilakukan dan sering penyandang lupa dengan apa yang sudah disampaikan, sehingga diperlukan suatu media. Metode booklet merupakan salah satu media yang bisa digunakan untuk memberikan edukasi dan mengingatkan penyandang Diabetes Melitus tentang perawatan Diabetes Melitus (5 pilar).

Faktor resiko DM yang dapat dikendalikan/ dikontrol yaitu kegemukan, hipertensi, riwayat sakit jantung, dislipidemia, kurang aktivitas fisik dan diet tidak seimbang. Penyakit diabetes dapat dikendalikan dengan mengatur pola makan / diet yang seimbang. Perilaku tidak patuh terhadap diet yang ditetapkan merupakan salah satu penyumbang kegagalan pengobatan DM. Sesuai dengan penelitian "faktor -faktor yang mempengaruhi kepatuhan diet pada pasien diabetes melitus tipe 2 di Kecamatan Sumbang Banyumas "dengan hasil pada variabel tingkat kepatuhan, sebagian besar berada pada tingkat tidak patuh, yaitu sebanyak 17 orang $(46,88 \%)$ (Arini, 2020).

Adapun faktor-faktor yang meningkatkan kepatuhan diet pasien menurut Niven (2012, dalam Hani Rosyada, dkk ,2020), antara lain: 1) meningkatkan pengetahuan dengan lebih sering berkomunikasi dengan tenaga kesehatan untuk memperoleh informasi yang cukup dan mendapat pengawasan yang baik; 2) adanya dukungan keluarga karena keluarga merupakan orang terdekat dengan pasien sehingga pasien merasa lebih senang dan hal ini akan meningkatkan kepercayaan pasien dalam mengelolah penyakitnya; 3) motivasi dan keyakinan individu, dimana motivasi yang paling kuat adalah berasal dari dalam diri sendiri dan keyakinan yang baik akan mempengaruhi perilaku pasien dalam mentaati aturan diet yang dianjurkan.

Pengelolaan diet yang baik harus memenuhi $3 \mathrm{~J}$ meliputi Jumlah, Jenis, dan Jadwal. Salah satu pengelolaan diet yang harus diatur adalah asupan karbohidrat, terutama jumlah dan jenis karbohidrat tertentu di dalam makanan. Ketidakpatuhan dalam penatalaksanaan pengelolaan diet $3 \mathrm{~J}$ oleh penderita DM akan menyebabkan tidak terkontrolnya kadar glukosa darah yang dapat memicu peningkatan produksi hormon insulin yang erat hubungannya dengan diabetes mellitus sehingga menimbulkan komplikasi seperti, stroke, gagal ginjal, jantung, kebutaan dan bahkan harus menjalani amputasi jika anggota badan menderita luka yang tidak biasa mengering darahnya (Risnasari, 2014).

Penelitian yang dilakukan oleh (Ropika Ningsih, 2018) didapatkan hasil adanya hubungan antara pengetahuan dengan tingkat kepatuhan terapi diet pada pasien Diabetes Mellitus Tipe 2 di Poliklinik Penyakit Dalam RSUD Dr. Achmad Mochtar tahun 2017 Lebih dari sebagian responden (56,4 \%) memiliki pengetahuan tinggi tentang terapi diet serta kepatuhan diet sedang pada pasien diabetes tipe 2 .

Prinsip anjuran makanan pada penderita DM tidak jauh berbeda dengan masyarakat pada umumnya, yaitu makanan seimbang dan sesuai dengan kebutuhan kalori dan zat gizi masing-masing individu. Pada penyandang DM perlu diberikan penekanan mengenai pentingnya keteraturan waktu makan, jenis 
dan jumlah kandungan kalori, terutama untuk penderita DM yang mengkonsumsi obat yang meningkatkan sekresi insulin. Adapun standar yang dianjurkan adalah makanan yang mengandung komposisi karbohidrat, protein, lemak, natrium, dan serat yang sesuai kecukupan gizi (Perkeni, 2015).

Teori model keperawatan yang peneliti kembangkan dalam penelitian ini yaitu konsep teori Health Promotion Model (HPM) dari Nola J. Pender di Puskesmas Cimahi Selatan. Teori Health Promotion Model memiliki cakupan faktorfaktor yang diperlukan untuk peningkatan perilaku kepatuhan, meliputi komponen internal dan eksternal yang terdapat dalam behavioral specific cognitinions and affect yaitu perceived self efficacy, activity related affect, dan interpersonal influence (Nursalam, 2015).

Berdasarkan hasil studi pendahuluan di wilayah kerja

\section{METODOLOGI PENELITIAN}

Penelitian ini menggunakan rancangan penelitian Praexperiment dengan desain One Grup Pretest Posttest. Populasi yang digunakan adalah pasien DM tipe 2 yang sedang berobat jalan usia 35-65 tahun, pengambilan sampel menggunakan purposive sampling dengan kriteria inkusi, Eksklusi

Penelitian dilakukan di

Puskesmas Cimahi Selatan pada bulan September-Oktober 2021. Peneliti menggunakan instrument kuesioner kepatuhan diet pada pasien DM tipe 2 dengan 16 pertanyaan yang sudah dilakukan pengujian validitas pada 16
Puskesmas Cimahi Selatan diperoleh data jumlah penduduk usia produktif (15-59 tahun) sebanyak 23.288 jiwa, lanjut usia (> 60 tahun) sebanyak 3.959 jiwa. Dari hasil studi pendahuluan dengan petugas kesehatan di Puskesmas Cimahi didapatkan jumlah penderita DM tipe 2 kunjungan lama bulan MaretMei 203 orang. Sedangkan kunjungan baru diperoleh data bulan Maret-Mei sebanyak 29 orang. Hasil wawancara beberapa penderita DM didapatkan informasi bahwa Sebagian besar dari mereka masih rendah dalam penatalaksanaan DM secara mandiri dikarenakan pengetahuan yang kurang terkait manajemen DM.

Berdasarkan latar belakang yang disusun, maka peneliti tertarik untuk melakukan penelitian dengan judul "Pengaruh Edukasi Self Management Diabetes (DSME) dengan menggunakan booklet terhadap kepatuhan diet pasien diabetes melitus tipe 2 di Puskesmas Cimahi Selatan?"

responden yang memiliki karakteristik yang sama dengan lokasi penelitian yaitu puskesmas cigugur tengah dengan nilai uji Jika $r$ hitung $\geq r$ table ( uji 2 sisi dengan sig 0,05$)$ dinyatakan valid valid dan reliabel dengan hasil Uji reliabisitas diperoleh nilai koefisien Alpha Cronbach, $\geq 0,60$. Kuesioner berupa pertanyaan untuk menentukan skor kepatuhan diet DM tipe 2 . Responden sesuai dengan kriteria inklusi dan eksklusi diambil 16 responden. Intervensi edukasi dengan media booklet dilakukan 1 kali selama 1 jam sebelumnya dilakukan pretest setelah 3 hari dilakukan posttest. Analisis data univariat dan bivariat menggunakan uji Mc Nemar. 
HASIL PENELITIAN DAN PEMBAHASAN Analisis Univariat

Table 1. kepatuhan diet pada penderita DM tipe 2 sebelum diberikan edukasi Self Management diabetes

\begin{tabular}{lcc}
\hline \multirow{2}{*}{ Variabel } & \multicolumn{2}{c}{ Pretest } \\
\cline { 2 - 4 } & $\begin{array}{c}\text { Frekuensi } \\
(\mathbf{f})\end{array}$ & $\begin{array}{c}\text { Persentasi } \\
(\%)\end{array}$ \\
\hline Patuh & 3 & 18,8 \\
Tidak Patuh & 13 & 81,3 \\
\hline Total & 16 & 100,0
\end{tabular}

Sumber: Data Primer.2021

Berdasarkan table 1 di atas diperoleh data hasil analisa gambaran kepatuhan diet pada penderita DM tipe 2 sebelum diberikan edukasi Self Management diabetes dengan media booklet di Puskesmas Cimahi Selatan pada 16 responden, bahwa hampir seluruhnya yaitu 13 orang $(81,3 \%)$ tidak patuh terhadap dietnya dan sebagian kecil yaitu 3 orang $(18,8 \%)$ patuh terhadap dietnya.

Table 2. Kepatuhan diet pada penderita DM tipe 2 setelah diberikan edukasi Self Management diabetes

\begin{tabular}{lcc}
\hline \multirow{2}{*}{ Variabel } & \multicolumn{3}{c}{ Posttest } \\
\cline { 2 - 3 } & Frekuensi & Persentasi \\
& $(\mathrm{f})$ & $(\%)$ \\
\hline Patuh & 13 & 81.3 \\
Tidak Patuh & 3 & 18.8 \\
\hline Total & 16 & 100.0 \\
\hline
\end{tabular}

Sumber: Data Primer,2021

Berdasarkan table 2 di atas diperoleh data hasil analisa gambaran kepatuhan diet pada penderita DM tipe 2 setelah diberikan edukasi Self Management diabetes dengan media booklet di Puskesmas Cimahi Selatan pada 16 responden, bahwa hampir seluruhnya yaitu 13 orang $(81,3 \%)$ patuh terhadap dietnya dan sebagian kecil yaitu 3 orang $(18,8 \%)$ tidak patuh terhadapdietnya.

Table 3. Pengaruh Edukasi Self Management Diabetes (DSME) dengan Media Booklet terhadap Kepatuhan Diet pasien DM tipe 2

\begin{tabular}{|c|c|c|c|c|c|}
\hline & & \multicolumn{2}{|c|}{$\begin{array}{l}\text { Kepatuhan diet } \\
\text { setelah edukasi }\end{array}$} & \multirow{2}{*}{ Total } & \multirow[b]{2}{*}{$p$} \\
\hline & & $\begin{array}{l}\text { Tidak } \\
\text { Patuh }\end{array}$ & Patuh & & \\
\hline \multirow{3}{*}{$\begin{array}{l}\text { Kepatuhan diet } \\
\text { sebelum edukasi }\end{array}$} & Tidak Patuh & 2 & 11 & 13 & 0.006 \\
\hline & Patuh & 1 & 2 & 3 & \\
\hline & Total & 3 & 13 & 16 & \\
\hline
\end{tabular}


Berdasarkan table 3 menunjukkan tentang distribusi tingkat kepatuhan diet pasien DM tipe 2 pada responden sebelum dan setelah intervensi. Pada uji McNemar diperoleh data hasil bahwa responden dengan kepatuhan diet sebelum edukasi dan setelah edukasi dengan kategori patuh yaitu sebanyak 11 orang, responden dengan kepatuhan diet sebelum edukasi dan setelah edukasi dengan kategori tidak patuh ada 2 orang. Hasil uji McNemar diperoleh nilai $p$ $=0,006$. Nilai $p(0,006)<a(0,05)$, maka Ho ditolak. Berarti dapat disimpulkan bahwa ada pengaruh edukasi self management diabetes (DSME) dengan media booklet terhadap kepatuhan diet pada penderita DM tipe 2 di Puskesmas Cimahi Selatan Tahun 2021.

\section{PEMBAHASAN}

Gambaran kepatuhan diet pada penderita DM tipe 2 sebelum diberikan edukasi Self Management diabetes dengan media booklet di Puskesmas Cimahi Selatan 2021.

Berdasarkan table 4.1 dari 16 responden pasien dengan kepatuhan diet sebelum dilakukan edukasi didapatkan $(81,3 \%)$ pasien tidak patuh terhadap kepatuhan dietnya. Hal ini sejalan dengan penelitian (Nanang, 2021) bahwa didapatkan hasil $53,7 \%$ tidak patuh terhadap jumlah makanan sesuai diet pasien Diabetes Melitus tipe 2 di Puskesmas Poto Tano Kabupaten Sumbawa Barat. Berdasarkan hasil analisa tersebut menunjukkan bahwa masih banyak responden yang tidak patuh terhadap perawatan mandiri terutama pada diet DM, hal ini kemungkinan karena belum terpaparnya informasi tentang diet DM dan hasil pengamatan peneliti dilapangan penyebabnya dari rendahnya kepatuhan diet pasien DM yaitu karena kurangnya pengetahuan, kurangnya dukungan keluarga, kurangnya motivasi dan keyakinan individu. Faktor lain dari hasil karakteristik kepatuhan diet yang buruk karena usia, dan pekerjaan.

Pada penelitian ini pasien yang menderita DM yaitu dari umur 46 - 65 tahun. Hasil ini sejalan dengan hasil penelitian (Nanang, 2021) bahwa sebagian besar pasien DM Tipe 2 di Puskesmas Poto Tano berumur > 45 tahun yaitu sebesar $85,1 \%$. Semakin bertambah usia seseorang pengetahuan dan pengalamannya akan semakin meningkat, semakin patuh untuk menaati peraturan karena kesembuhannya. Namun secara alamiah akan terjadi penurunan fungsi untuk merawat diri sendiri maupun berinteraksi dengan masyarakat sekitarnya, dan akan semakin bergantung pada orang lain. Sebagian besar responden berpendidikan SD. Hal ini sejalan dengan pendapat (Retno Ningsih, 2020) didapatkan informasi bahwa hampir setengahnya berpendidikan SD di RSUD Imanuddin Pangkalan Bun. Kepatuhan seseorang tidak hanya dipengaruhi pendidikan yang tinggi, tetapi juga dapat dipengaruhi oleh pengalaman atau kebiasaan yang dilakukan seseorang dalam menghadapi penyakit yang dideritanya. Keterampilan dan pengetahuan tersebut dapat diperoleh dari petugas kesehatan yang dikunjunginya. Hal ini sesuai dengan pernyataan dari (Ropika Ningsih, 2018) bahwa Pendidikan (edukasi) kesehatan merupakan bentuk upaya persuasi atau pembelajaran kepada masyarakat bersedia melakukan tindakantindakan untuk memelihara dan meningkatkan taraf kesehatannya, mencegah timbulnya penyakit, mempertahankan taraf kesehatan 
yang sudah ada,memaksimalkan fungsi dan peran pasien selama sakit serta membantu pasien dan keluarga mengatasi masalah kesehatan.

Untuk jenis kelamin, sebagian besar responden berjenis kelamin perempuan 9 orang $(56,3 \%)$. Hal ini sejalan dengan hasil penelitian (Retno Ningsih, 2020) bahwa sebagian besar responden berjenis kelamin perempuan (60\%). Wanita cenderung lebih patuh dalam mentaati peraturan. sesuai dengan pendapat Saguni (2014) gender di dalam korteks merupakan Stereotype emosional utama. Mematuhi, mengikuti peraturan serta tampil rapi dan teratur adalah perilaku yang biasanya berhubungan dengan anak perempuan dengan anak perempuan daripada anak lakilaki. Pendekatan biologis menjelaskan perbedaan otak perempuan otak perempuan dan otak laki-laki. Didalam corpus collosum, sekumpulan sel saraf yang menggabungkan dua belahan otak. Corpus collosum pada perempuan lebih besar daripada laki-laki dan ini menjelaskan mengapa perempuan lebih sadar dibandingkan dengan laki-laki tentang emosi mereka sendiri dan emosi orang lain.

Sebagian kecil responden bekerja. Pekerjaan merupakan salah satu faktor yang mempengaruhi kepatuhan. Hal ini sejalan dengan penelitian (Nanang, 2021) yang berjudul Analisis Faktor yang Berhubungan Dengan Kepatuhan Diet Penderita Diabetes Melitus mendapatkan hubungan yang signifikan antara pekerjaan dengan kepatuhan menaati aturan diet DM $(p=0,004)$ dimana responden yang tidak bekerja berpeluang 3,923 kali patuh dengan program diet dibandingkan dengan responden yang bekerja.

Berdasarkan uraian diatas dapat disimpulkan bahwa kepatuhan pasien dalam mengontrol jumlah makanan akan bermanfaat untuk pasien mengontrol/mencegah terjadinya komplikasi atau penurunan status kesehatan pada pasien DM, maka perlu adanya peran petugas puskesmas untuk memberikan informasi kepada pasien Diabetes Melitus pentingnya kepatuhan jumlah makanan yang dikonsumsi perharinya agar tidak terjadinya peningkatan glukosa darah secara mendadak dan tidak terkontrol akan mengganggu kondisi kesehatannya untuk beraktivitas.

\section{Gambaran kepatuhan diet pada penderita DM tipe 2 setelah diberikan edukasi Self Management diabetes dengan media booklet di Puskesmas Cimahi Selatan 2021}

Berdasarkan table 4.2 di atas diperoleh data hasil analisa gambaran kepatuhan diet pada penderita DM tipe 2 setelah diberikan edukasi Self Management diabetes dengan media booklet di Puskesmas Cimahi Selatan pada 16 responden, bahwa hampir seluruhnya yaitu 13 orang $(81,3 \%)$ patuh terhadap dietnya. Hal ini sejalan dengan penelitian (Risnasari, 2014) bahwa hampir seluruhnya responden dengan kategori patuh yaitu sebesar $93.3 \%$. Berdasarkan hasil postest bahwa terdapat perubahan kepatuhan diet responden, hal ini karena responden sebelumnya tidak patuh terhadap diet menunjukkan perubahan saat posttest menjadi patuh.

Peningkatan kepatuhan diet ini terjadi akibat tambahan informasi salah satu upaya dalam meningkatkan pengetahua responden yaitu dengan memberikan edukasi Self Management Diabetes dengan media booklet. Diabetes Self Management Education (DSME) adalah proses untuk mengajari orang mengelola diabetesnya, salah satunya telah dianggap sebagai 
bagian penting dari manajemen klinis diabetes sejak tahun 1930an. DSME adalah proses kolaboratif dimana pendidik diabetes membantu orang dengan atau beresiko diabetes memperoleh pengetahuan dan pemecahan masalah dan keterampilan koping yang diperlukan untuk mengatasi mengelola penyakit dan kondisi yang terkait secara mandiri. Pembahasan dalam Booklet tersebut mengenai 5 pilar penanganan utama pada pasien DM tipe 2 yaitu edukasi, diet nutrisi medik, latihan jasmani, obat farmakologi dan monitoring kadar gula darah.

Edukasi memegang peranan
yang sangat penting dalam
penatalaksanaan DM tipe 2 karena
pemberian edukasi kepada pasien
dapat merubah perilaku pasien
dalam melakukan perawatan mandiri diabetes melitus. Merubah perilaku pada penyandang Diabetes tidak mudah, diperlukan motivasi yang diakukan secara terus menerus. Motivasi yang diperlukan dapat dengan berbagai cara salah satunya dengan memberikan edukasi untuk selalu mengingatkan tentang perawatan penyandang Diabetes Melitus (5 pilar) setiap saat. Edukasi yang diberikan secara langsung sudah sering dilakukan dan sering penyandang lupa dengan apa yang sudah disampaikan, sehingga diperlukan suatu media. Metode booklet merupakan salah satu media yang bisa digunakan untuk memberikan edukasi dan mengingatkan penyandang Diabetes Melitus tentang perawatan Diabetes Melitus (5 pilar) (Fitri Suciana, 2019).

Berdasarkan pengamatan peneliti bahwa edukasi Self Management Diabetes (DSME) sangat diperlukan untuk meningkatkan kepatuhan diet pada pasien DM tipe 2. Penelitian ini juga sejalan dengan penelitian (Deni, 2018) didapatkan hasil adanya hubungan antara pengetahuan dengan tingkat kepatuhan terapi diet pada pasien Diabetes Mellitus Tipe 2 di Poliklinik Penyakit Dalam RSUD Dr. Achmad Mochtar tahun 2017 Lebih dari sebagian responden (56,4 \%) memiliki pengetahuan tinggi tentang terapi diet serta kepatuhan diet sedang pada pasien diabetes tipe 2 (Deni, 2018).

Pengaruh Edukasi Self Management Diabetes (DSME) dengan Media Booklet terhadap Kepatuhan Diet pasien DM tipe 2 di Puskesmas Cimahi Selatan tahun 2021

Hasil penelitian didapatkan ada pengaruh edukasi self management diabetes (DSME) dengan media booklet terhadap kepatuhan diet pada pasien DM tipe 2 di Puskesmas Cimahi Selatan 2021. Salah satu penyebab rendahnya angka kepatuhan diet DM tipe 2 adalah masih disebabkan karena kesadaran penderita dalam melakukan perawatan kesehatan mandiri secara teratur karena kurang dukungan keluarga, untuk mengawasi bagaimana kepatuhan diet pasien dan stress. Penyebab dari faktor tersebut karena kurangnya pengetahuan terhadap perawatan diabetes terutama pada kepatuhan diet.

Edukasi memegang peranan yang sangat penting dalam penatalaksanaan DM tipe 2 karena pemberian edukasi kepada pasien dapat merubah perilaku pasien dalam melakukan perawatan mandiri diabetes melitus. Merubah perilaku pada penyandang Diabetes tidak mudah, diperlukan motivasi yang diakukan secara terus menerus. Motivasi yang diperlukan dapat dengan berbagai cara salah satunya dengan memberikan edukasi untuk selalu mengingatkan tentang 
perawatan penyandang Diabetes Melitus ( 5 pilar) setiap saat.

Edukasi yang diberikan secara langsung sudah sering dilakukan dan sering penyandang lupa dengan apa yang sudah disampaikan, sehingga diperlukan suatu media. Metode booklet merupakan salah satu media yang bisa digunakan untuk memberikan edukasi dan mengingatkan penyandang Diabetes Melitus tentang perawatan Diabetes Melitus (5 pilar) (Fitri Suciana, 2019).

Berdasarkan table 4.3 menunjukkan tentang distribusi tingkat kepatuhan diet pasien DM tipe 2 pada responden sebelum dan setelah intervensi. Pada uji McNemar diperoleh data hasil bahwa responden dengan kepatuhan diet sebelum edukasi dan setelah edukasi dengan kategori patuh yaitu sebanyak 11 orang, responden dengan kepatuhan diet sebelum edukasi dan setelah edukasi dengan kategori tidak patuh ada 2 orang. Hasil uji McNemar diperoleh nilai $p$ $=0,006$. Nilai $p(0,006)<a(0,05)$, maka Ho ditolak. Berarti dapat disimpulkan bahwa ada pengaruh edukasi self management diabetes (DSME) dengan media booklet terhadap kepatuhan diet pada penderita DM tipe 2 di Puskesmas Cimahi Selatan Tahun 2021.

Pada penelitian ini dilakukan selama 7 hari dengan intervensi

\section{KESIMPULAN}

Diketahui dari 16 responden dengan Kepatuhan diet responden sebelum edukasi 13 orang $(81,3 \%)$ hampir seluruhnya kepatuhan terhadap dietnya tidak patuh. Dan dari 16 responden dengan Kepatuhan diet responden setelah edukasi 13 orang $(81,3 \%)$ hampir seluruhnya kepatuhan dietnya patuh. Ada pengaruh edukasi Self Management diabetes (DSME) dengan media pemberian edukasi kepatuhan diet terhadap pasien DM Tipe 2, dengan masa pertemuan sebanyak $2 x$, setiap pertemuan memakan waktu sebanyak 1 jam. Selanjutnya peneliti mengevaluasi hasil dari pemberian edukasi pada saat hari ke 3 setelah pemberian edukasi tersebut.

DSME adalah proses kolaboratif dimana pendidik diabetes membantu orang dengan atau beresiko diabetes memperoleh pengetahuan dan pemecahan masalah dan keterampilan koping yang diperlukan untuk mengatasi mengelola penyakit dan kondisi yang terkait secara mandiri. Menurut model teori keperawatan J Pender untuk memberikan promosi kesehatan dimana model yang dikembangkan yaitu promotion dan preventive untuk meningkatkan derajat kesehatan. Teori Pender konsisten dengan semua teori yang memandang pentingnya promosi kesehatan dan pencegahan penyakit adalah sesuatu yang logis dan ekomnomis. Teori ini sangat lengkap untuk melakukan kegiatan yang berhubungan dengan tingkat promotif dan preventif. DSME menggunakan media booklet dimana booklet digunakan selain untuk edukasi juga digunakan untuk mengingatkan penyandang Diabetes Melitus tentang perawatan Diabetes Melitus.

booklet terhadap kepatuhan diet pasien DM tipe 2.

Saran untuk Puskesmas Cimahi Selatan berdasarkan hasil penelitian ini bisa dijadikan informasi dan masukan untuk dapat meningkatkan kegiatan edukasi secara teratur dan terjadwal dengan media Booklet tentang kepatuhan diet. Hal ini adalah upaya preventif dan promotif bagi masyarakat dan khususnya pasien DM tipe 2 . Puskesmas Cimahi Selatan bisa 
melakukan kerja sama dengan STIKes Budi Luhur untuk membantu program DM tipe 2 secara home visit terhadap masyarakat.

\section{DAFTAR PUSTAKA}

A. D. Association. (2016). Standards of Medical Care in Diabetes, Diabetes Care, vol. 39, no. 1.

Arini, d. E. (2020). Faktor-faktor yang memPengaruhi Kepatuhan Diet Pada Pasien Diabetes Melitus Tipe2 di Kecamatan Sumbang Banyumas. Vol 1. no 1.

CA, S. a. (2016). Patient Education and Counseling Diabetes Self-Management Education for Adults with type 2 Diabetes Mellitus : $A$ systemic revie of the effect on glycemic control," vol. 99, no. 6, pp. 26-43.

Deni, R. N. (2018). Hubungan pengetahuan dengan Kepatuhan Diet pada pasien DM Tipe II di Poliklinik Penyakit Dalam RSUD Dr. Achmad Mochtar Kota Bukittinggi. Jurnal Keperawatan, 15 (1).

Depkes. (2018). Riset Kesehatan Dasar (Riskesdas). Jakarta: Depkes.

Dinkes. (2018). Profil Kesehatan Kota Cimahi. Cimahi: Dinas Kesehatan Pemerintah Kota Cimahi.

Fitri Suciana, D. M. (2019). Penatalaksanaan 5 Pilar Pengendalian DM Terhadap Kualitas Hidup pasien DM tipe 2. Jurnal IImia STIKES Kendal Vol 9 No 4, 311-318.

Kemenkes, R. (2019). Info DATIN Hari Diabetes Sedunia Tahun 2018. Jakarta: Direktorat Pencegah dan Pengendalian Penyakit Tidak Menular.
Malanda, B. (2019). International Diabetes Federation Diabetes Atlas, 9th edition. International Diabetes Federation.

Nanang, P. (2021). Gambaran Kepatuhan Diet pasien Diabetes Melitus Tipe 2 di Puskesmas Poto Tano Kabupaten Sumbawa barat . universitas Andalas.

Notoatmodjo., S. (2013). Pendidikan dan Perilaku Kesehatan Jakarta: Rineka Cipta, 2013. Jakarta: Rineka Cipta.

Nursalam. (2015). Metodologi ilmu keperawatan. edisi 4. Jakarta: Salemba Medika.

Perkeni. (2015). Pengelolaan dan Pencegahan Diabetes Mellitus tipe 2. Perkumpulan Endokrinologi Indonesia.

Retno Ningsih, z. S. (2020). Aktifitas Fisik sehari- hari, dan sosiodemografi penederita hipertensi dalam upaya mencegahkomplikasi

hipertensi Di Kabupaten Kotawaringin Barat. Jurnal Internasional kesehatan, Pendidikan dan Sosial (IJHES), 24-30.

Risnasari, N. (2014). Hubungan tingkat kepatuhan diet pasien diabetes mellitus dengan munculnya komplikasi di Puskesmas Pesantren II Kota Kediri . Ip2m.unpkediri vol. 25, no. 1, 15-19.

Ropika Ningsih, R. D. (2018). Hubungan Pengetahuan Dengan Kepatuhan Diet Pada Pasien Diabetes Mellitus Tipe II Di Poliklinik Penyakit Dalam RSUD Dr. Achmad Mochtar Kota Bukittinggi. STIKes Insan Cendekia Medika Jombang. Vol 15. No 1. 